\section{Type 1 diabetes in children and adolescents - a need for multi-pro- fessional team intervention}

\section{Cukrzyca typu 1 u dzieci i młodzieży - potrzeba interwencji interdyscy- plinarnego zespołu specjalistów}

\author{
Izabela Krzyśko, Sabina Przewoźniak, Bogda Skowrońska, Elżbieta Niechciał, \\ Anna Gertig-Kolasa, Piotr Fichna
}

Department of Pediatric Diabetes and Obesity, Poznan University of Medical Sciences, Poznan, Poland

\section{Key words}

type 1 diabetes mellitus, children, adolescents, inter-professional team, healthcare team

\begin{abstract}
Type 1 diabetes is defined by absolute insulin deficiency caused by autoimmune-mediated pancreatic $\beta$-cell destruction and is one of the most frequently recognized chronic diseases among children. Its therapy consists of intensive insulin treatment with multiple daily injections or continuous subcutaneous insulin infusion, constant monitoring of blood glucose level and adjusting insulin dose according to glycemia, as well as planned meals and physical exercise. Balanced diet and regular physical activity are further indispensable components of diabetes therapy. Patient's mental condition affects almost all aspects of disease management. In this paper through the analysis of the problems and difficulties arising from the nature of the disease and the nature of this particular group of patients, which are children and adolescents, we are try to show how crucial is that a trained dietitian, psychologist and educator would be equally present in the pediatric diabetes team together with pediatric endocrinologist, so that they collectively could provide professional and comprehensive care to the type 1 diabetes patient. All members of medical team must be easily available in specialized outpatient clinic or/and in hospital ward and should be ready to devote enough time for children with diabetes and their parents.
\end{abstract}

Pediatr. Endocrinol. 2015.14.3.52.41-46.

(C) Copyright by PTEiDD 2015

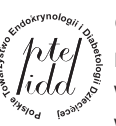

c Copyright by PTEiDD 2015

redakcja@pteidd.pl

www.endokrynologiapediatryczna.pl www.pteidd.pl
Klinika Diabetologii i Otyłości Wieku Rozwojowego, Uniwersytet Medyczny w Poznaniu, Poznań, Polska

\section{Słowa kluczowe}

cukrzyca typu 1, dzieci, młodzież, zespół interdyscyplinarny, zespół terapeutyczny

\section{Streszczenie}

Cukrzyca typu 1 jest wynikiem całkowitego niedoboru insuliny, spowodowanego zniszczeniem komórek $\beta$ trzustki w przebiegu procesu autoimmunologicznego i jest jedną z najczęściej rozpoznawanych chorób przewlekłych wśród dzieci. Jej terapia polega na intensywnym leczeniu insulina za pomoca wielokrotnych wstrzyknięć lub ciąglego podskórnego wlewu insuliny, ciągłym monitorowaniu poziomu glukozy we krwi oraz dostosowywaniu dawki insuliny w zależności od poziomu glikemii, planowanych positków i aktywności fizycznej. Zrównoważona dieta oraz regularna aktywność fizyczna są kolejnymi niezbędnymi elementami leczenia cukrzycy, a stan psychiczny pacjenta wplywa na niemal wszystkie aspekty choroby. W niniejszej pracy poprzez analizę problemów i trudności wynikających ze specyfiki cukrzycy w wieku rozwojowym staramy się pokazać, jak ważne jest, by wyszkolony dietetyk, psycholog i edukator byli na równi obecni w zespole terapeutycznym wraz z endokrynologiem/ diabetologiem dziecięcym, tak aby wspólnie mogli zapewnić profesjonalna i kompleksowa opieke nad pacjentem z cukrzyca typu 1. Wszyscy członkowie zespołu terapeutycznego powinni być łatwo dostępni w przychodni specjalistycznej i / lub w oddziale szpitalnym i być w stanie poświęcić wystarczająco dużo czasu dla dzieci chorych na cukrzycę i ich rodziców.

Endokrynol. Ped. 2015.14.3.52.41-46.

(c) Copyright by PTEiDD 2015

Correspondence address / Adres do korespondencji: Izabela Krzyśko, ul. Szpitalna 27/33; 60-572 Poznań, tel.: +48618491 420, fax: +48618491 492, e-mail: izabela.krzysko@gmail.com 


\section{Introduction}

Type 1 diabetes, an autoimmune disease, it is defined by absolute deficiency of insulin secretion caused by autoimmune-mediated pancreatic $\beta$-cell destruction. The process of destruction is asymptomatic until most of $\beta$-cells are destroyed. The etiology is multifactorial and unclear [1,2]. It is estimated that nowadays approximately 500,000 children all over the world suffer from type 1 diabetes, and $26 \%$ of them are from Europe [3]. These data confirm that type 1 diabetes is one of the most frequently recognized chronic diseases among children and among other chronic diseases is exceptional: it requires a complex and multi-dimensional therapy which involves not only the patients but also their families and care-givers. After the diagnosis, patients and their families have to work out a change in their daily habits and adjust them to the multidimensional control of diabetes [4].

\section{General rules of type 1 diabetes treatment in the childhood}

\section{Insulin therapy}

The therapy of type 1 diabetes consists of intensive insulin treatment with multiple daily injections, or pump therapy with constant dose adjustments in order to mimic as much as possible normal physiology of human body [1]. This kind of treatment requires constant monitoring of blood glucose level and adjusting insulin dose according to glycemia, as well as planned meals and physical activity. The patient should understand well the aim of insulin action (better than glycemia result on glucometer) and the clinical symptoms of its deficit or excess.

\section{Diet}

Patient's diet is one of the crucial components of type 1 diabetes therapy. It has not been proved that nutritional needs of diabetic children are different from those of non-diabetic ones. The most essential is that total nutrient intake is sufficient to balance the total daily energy consumption and its temporary variations in order to achieve ideal body weight and sustain normal growth and development [1]. Patient's meal plan should include food from every group of products recommended for daily intake. What is paramount - no calorie or carbohydrate restrictions should be imposed in order to achieve low blood glucose levels [5].
Diabetes management aims most of all at sustaining normal or near-normal blood glucose level to prevent long-term consequences, to control lipids and lipoproteins in plasma and blood pressure to prevent the risk of vascular disease and also to achieve and sustain required body weight [6]. However, research shows that diet of adolescents with diabetes type 1 is deficient and does not meet recommendations [7]. Diabetes diet management must consider the exogenous insulin pharmacokinetics and bidirectional programming for meals ingestion and insulin action intervals. Moreover, the meals should be adjusted to physical activity and expected glucose utilization to avoid energy deficit and risk of hypoglycemia as well. Finally, sometimes meals are served as intervention treatment at hypoglycemia. In all the above mentioned circumstances, the meal quality (high or low glycemic index, for example) and energy load should be recognized and appropriately applied by the patient or his/her care givers.

\section{Physical activity}

Physical activity is another inseparable element of diabetes management. Regular physical exercise improves insulin action and lowers the risk of diabetes-related complications [8]. Moreover, physical exercise has been found to increase the lifespan of type 1 diabetes patients [9]. According to the guidelines issued by most diabetes institutions, the youth with diabetes should be encouraged to perform moderate to intense physical activity lasting at least 60 minutes daily [10]. However they constitute a group with high risk of hypoglycemia during and immediately after exercise (even up to 12 hours) [11] and nocturnal hypoglycemia is a serious issue with children and adolescents with type 1 diabetes [12]. Although exercise usually causes a reduction in blood glucose level, in certain circumstances it may cause hyperglycemia [13]. Even patients in good metabolic control may experience hyperglycemia during and after strenuous exercise [14], possibly due to the significant rise of catecholamines which lower glucose consumption [15]. Another explanation is the evident insulin deficit in course of physical activity, which evokes blood glucose decline only with concomitant insulin action. Insulin deficit will limit oxidative glycolysis, will not stop gluconegenesis and will promote burning fatty acids to keton compounds. The art of treatment is to know the individual patient's reaction to exercise, insulin and diet together to keep a proper balance among them.

\footnotetext{
Type 1 diabetes in children and adolescents - a need for multi-
} -professional team intervention 


\section{Family and social circumstances influence on dia-} betes care

\section{Diagnosis}

Medical diagnosis of type 1 diabetes implies not only pediatric endocrinologist care for the affected child and not only pharmacological therapy. The above pointed out general rules of diabetes control are really difficult even for open minded, smart patients and their parents. Thus most of them have serious emotional problems and shortage of their previous knowledge to understand and to introduce a proper disease care into the everyday practice. Additionally, a lot of emotional factors affect child and parents immediately and later after the diagnosis. Every child diagnosed with type 1 diabetes, together with the family, should be offered psychological support to help them cope with the new situation. The educator's task is to pass theoretical and practical rudiments of insulin therapy, glycemia control, symptoms of too high or too low levels of blood glucose. This should be immediately followed by counseling by a dietician and physiotherapist who will provide them with essential knowledge on dietary requirements and influence of physical activity on diabetes patients. The comprehensive care of diabetes patients is required throughout all their lives, as at different stages different support is necessary.

\section{Back to school reality}

After a short stay in the hospital, patients return to the environment where they functioned before. For younger school children, going back to their daily routine is much harder because most of the day they spend under the care of teachers who, taking responsibility for the children's safety, should also feel responsible for the disease management. The way they do this, or if they undertake the task at all, depends not only on their personalities, but primarily on their understanding of the disease.

That is the place where again educators should play the vital role by passing the knowledge of the disease and insulin therapy to teachers and students from the child's school. Such attitude may help create a safe environment for young patients where they will be less discriminated by their peers or excluded from school activities, which frequently takes place because of people's lack of knowledge and fear of the unknown.

Izabela Krzyśko, Sabina Przewoźniak, Bogda Skowrońska, Elżbieta Niechciał, Anna Gertig-Kolasa, Piotr Fichna

\section{Age-dependent diabetic challenges}

Type 1 diabetes may affect children of different ages: between infancy up to mature adolescents. Therefore their biological conditions and reactions to the treatment are changing along with their somatic and psychological development. Diabetic education and/or acceptance of disease has many barriers depending on patient's age.

The youngest children with diabetes cannot fully rationally understand their situation and are expected to cooperate with parents and/or care givers by acceptance of glucose measurement and tolerance of personal insulin pump or insulin shots, and obedience to meal regimen and activity control. So they are mainly passive in the disease course. The important role of parents or pre-school care givers depends on careful observations of child's behavior and flexible reactions to glycemia results, meals and activity.

Young school children can better understand their illness and cooperate with parental instructions under teacher's supervision. Adolescents with diabetes are almost independent in good as well as in poor diabetes control. They reflect previous parental guidance related to their knowledge, responsibility, accuracy etc. in their diabetes selfcontrol. This life period has its own specific difficulties in course of diabetes due to somatic and psychological maturity.

Children and adolescents with type 1 diabetes manifest changes in insulin sensitivity / insulin resistance, have different eating behavior and physical activity patterns according to consecutive stages of their development. They are not stable any time with disease demands and all members of the multiprofessional team have to support them adequately to a situation.

\section{Peri-pubertal difficulties}

In puberty, children's calorific intake increases along their general growth. This fact, together with the importance of a balanced diet to maintain good metabolic control, calls for dietary intervention. Anabolic effect of insulin which causes increased appetite when insulin is overdosed can lead to excess weight gain, as well as fear of hypoglycemia leading to frequent snacks consumed between meals. Obesity if occurs contributes to increase of insulin resistance and is an additional risk factor for occurrence of cardiovascular disease in the future.

Moreover frequent weight loss and weight gain may be another reason for eating disorders. Thus regular psychological counseling is crucial in type 1

Endokrynol. Ped. 2015.14.3.52.41-46 43 
diabetes management. With age, young patients tend to change their physical activity; some of them will take up a sport discipline or will express the intention of doing so. To do it safely, without any harm to their health, they should receive responsible expert support on how a particular type of exercise affects glycemia and their growing body. Young patients make attempts to appear better than their healthy colleagues and may compete too much in sport activity. That is why they need additional education in this field and additional coach's supervision.

The process of sexual maturation may also be the biological and psychological problem to teenagers with diabetes. The natural occurrence of insulin resistance needs improvement of its dosing. The initiation of sexual contacts may be used to confirm their own value among peers, however, it may also be confusing or risky for diabetes control. Adolescents should be educated how prepare also their disease for adult biology.

\section{Discouragement and rebellion}

In children with established diabetes, the unlimited duration of the disease requiring constant control and adjustment to the limitations that it imposes raises another problem. "Adolescent rebellion" hinders diabetic therapy during the transition period toward independence in management without adult supervision.

These factors make adolescence the most critical time in disease management and result in frequent deterioration in therapy or even its total abandonment by young patients, which leads to recurrent hospitalization, chronic metabolic imbalance, and problems in the peer group. Any therapeutic actions are of limited value unless the patient as well as his/her parents receive individual psychological counseling or group therapy. Extended hyperglycemia and poor metabolic control severely increase the risk of late diabetes complications. It would be advisable to offer adolescent patients and their families participation in workshops educating them in gradual shift towards self-management supplemented with motivation counseling.

\section{Mental condition in course of childhood and ado- lescent diabetes}

\section{Type 1 diabetes impact on psychological disorders among children with $11 D M$}

The development of the disease, particularly accompanied by acute symptoms, contributes to the patient's emotional distress, self-guilt, lower selfesteem, helplessness, dependence on others and a general feeling of misfortune. Hypoglycemia episodes also evoke the feeling of insecurity and lack of control over the situation [16]. Patient's mental condition affects almost all aspects of disease management. Mismanagement often comes from emotional problems which require diagnosis and psychological support and counseling [6]. Patients with diabetes frequently suffer from depression, emotional distress (mainly anxiety disorder), low mood, moodiness, insecurity and helplessness [16].

Emotional problems starts to occur at the time of diagnosis - according to one of the studies approximately $30 \%$ of children develop adaptive disorders within three months after diagnosis [17], another shows that about $9 \%$ of teens with type 1 diabetes manifests moderate or severe depressive symptoms (more often reported in girls) [7] and one of the longterm studies to observe young patients with type 1 diabetes into adulthood found that $42 \%$ of them had at least one episode of psychiatric disorders - $26 \%$ were depressive disorders, $20 \%$ - anxiety disorders and $16 \%$ behavior disorders [18].

Studies show that also patients' parents experience increased anxiety (e.g., symptoms of fear and depression) after their child has been diagnosed with diabetes; also after the initial period of adjustment, parents seem to experience more symptoms of depression and general emotional distress [18]. In a large European study one year after the diagnosis $20.4 \%$ of mothers and $8.3 \%$ of fathers of children with type 1 diabetes manifested permanent signs and symptom of posttraumatic stress disorder [19].

Diabetic teenagers, particularly females, are also more prone to develop eating disorders [17]. Among the factors contributing to the developing of eating disorders, one should mention weight gain upon the initiation of insulin therapy or blood glucose level normalization, dietary restrictions due to the diabetes management, as well as insulin omission as a way to 'purge' by inducing glycosuria [20]. The estimated incidence of eating disorders among adolescents with type 1 diabetes is $10 \%$ (twice more as among girls without diabetes) [18], further $10-15 \%$ fulfill the criteria for subclinical eating disorders [20].

\section{Family burden with child suffering from t1DM}

It has been shown that serious conflicts between adolescent patients and their parents as well as insufficient parents' involvement in diabetes therapy predestine poorer metabolic control

\footnotetext{
Type 1 diabetes in children and adolescents - a need for multi-
} -professional team intervention 
of the disease, while positive family attitude, their support and close relations motivate to better selfcare and diabetes management [19]. Family conflicts concerning the therapy tend to intensify at the onset of puberty. Research shows that parents often transfer the responsibility for the diabetes management onto the children too early, which may lead to the disproportion between the tasks of self-management and the psychological maturity of the patients. This, to a certain extent, may explain deterioration in the disease management during puberty [18]. As children' cognitive skills develop, parents and caregivers should assist them to transition to more independent, adequate for the particular age, daily self-management [1].

Poor family economy, parents' divorce or long absence from home, any sort of other difficulties such as a serious disease of another family member or pathologies like alcoholism, orphanage destroy proper diabetes control at any age of the patient.

\section{Concluding remarks}

In order to face the daily tasks and challenges that the diagnosis of type 1 diabetes brings on, pa- tient is required to assume a proactive approach to the constraints which the disease imposes. Frequently, however, patients are reluctant to do so and lack in motivation to follow the regimen of glycemic and diet [16] and physical activity control. Children and adolescents with type 1 diabetes need sufficient support from their family members, and also from their friends, teachers, sport coaches and any other responsible adults on their life road.

Taking into account all these aspects of diabetes management, it is evident that for effective care equal involvement of the patient's doctor as well as education, diet, mental health and physical exercise specialists is required. Thus immediately after the diagnosis, the patient should be placed in the care of an interdisciplinary team of specialists. Therefore, it is crucial that a trained dietitian, psychologist and educator should be equally present in the pediatric diabetes team together with pediatric endocrinologist so that they collectively could provide professional and comprehensive care to the type 1 diabetes patient.

\section{References / Piśmiennictwo}

1. Brook C.G.D., Brown R.S.: Endokrynologia pediatryczna. Elsevier Urban \& Partner, Wrocław 2013

2. Craig M., Jefferies C., Dabelea D. et al.: Definition, epidemiology, and classification of diabetes in children and adolescents (ISPAD Clinical Practice Consensus Guidelines 2014 Compendium). Pediatr. Diabetes., 2014:15, 4-17.

3. Aguiree F., Brown A., Cho N. et al.: IDF Diabetes Atlas. 2013

4. Chojnacka-Szawłowska G.: Psychologiczne aspekty przewlekłych chorób somatycznych. Vizja Press \& IT, Warszawa 2012.

5. Suskind D., Lenssen P.: Algorytmy żywienia dzieci. Elsevier Urban \& Partner, Wrocław 2013.

6. Diabetologia Kliniczna 2013, t. 2, supl 2013, t. 2, supl. A.: Zalecenia kliniczne dotyczące postępowania u chorych na cukrzyce, 2013. Diabetologia Kliniczna, 2013, 3-52.

7. http://www.cdc.gov/diabetes/risk/age/ youth.html.
8. Galassetti P., Riddell M.C.: Exercise and type 1 diabetes (T1DM). Compr Physiol., 2013 Jul:3(3), 1309-1336.

9. Moy C.S., Songer T.J., LaPorte R.E. et al.: Insulin-dependent diabetes mellitus, physical activity, and death. Am. J. Epidemiol., 1993 Jan 1:137(1), 74-81.

10. Kenneth R., Peter A., Gary S. et al.: ISPAD Clinical Practice Consensus Guidelines 2009 Compendium Exercise in children and adolescents with diabetes. Pediatr. Diabetes, 2009:10, 154-168

11. McMahon S.K., Ferreira L.D., Ratnam $N$. et al.: Glucose requirements to maintain euglycemia after moderateintensity afternoon exercise in adolescents with type 1 diabetes are increased in a biphasic manner. J. Clin. Endocrinol. Metab., 2007 Mar:92(3), 963-968

12. Juvenile Diabetes Research Foundation Continuous Glucose Monitoring Study Group. Prolonged nocturnal hypoglycemia is common during 12 months of continuous glucose monitoring in children and adults with type 1 diabetes. Diabetes Care, 2010 May:33(5), 1004-1008.

13. Marliss E.B., Vranic M.: Intense exercise has unique effects on both insulin release and its roles in glucoregulation: implications for diabetes. Diabetes, 2002 Feb:51 Suppl 1, S271-83.

14. Mitchell T.H., Abraham G., Schiffrin A. et al.: Hyperglycemia after intense exercise in IDDM subjects during continuous subcutaneous insulin infusion. Diabetes Care, 1988 Apr:11(4), 311317.

15. Fahey A.J., Paramalingam N., Davey R.J. et al.: The effect of a short sprint on postexercise whole-body glucose production and utilization rates in individuals with type 1 diabetes mellitus. J. Clin. Endocrinol. Metab., 2012 Nov:97(11), 4193-4200.

16. Kirenko J., Byra S.: Zasoby osobiste w chorobach psychosomatycznych. Wydawnictwo Uniwersytetu Marii Curie-Skłodowskiej, Lublin 2011.

17. Northam E.A., Todd S., Cameron F.J.: Interventions to promote optimal health outcomes in children with Type 
1 diabetes-are they effective? Diabet. Med., 2006:23, 113-121.

18. Jaser S.S.: Psychological problems in adolescents with diabetes. Adolesc. Med. State. Art. Rev., 2010 Apr:21(1), 138-151, x-xi.
19. Cameron F.J., Northam E.A., Ambler G.R. et al.: Routine psychological screening in youth with type 1 diabetes and their parents: A notion whose time has come? Diabetes Care, 2007:30(10), 2716-2724.
20. Frank M.R.: Psychological issues in the care of children and adolescents with type 1 diabetes. Paediatr. Child Health, 2005:10(1), 18-20. 